\title{
Effects of Two Different Energy Sources in Total Mixed Diets on the Performances and Blood Metabolites of Lactating Boerka Goats
}

\author{
Ginting SP, Tarigan A, Simanihuruk K, Antonius, Solehuddin \\ Goat Research Station, P.O. Box 1 Galang, North Sumatera \\ Email: simonginting04@gmail.com
}

(received 09-01-2020; revised 18-02-2020; accepted 18-02-2020)

\begin{abstract}
ABSTRAK
Ginting SP, Tarigan A, Simanihuruk S, Antonius, Solehuddin. 2020. Pengaruh dua sumber energi berbeda dalam pakan komplit terhadap performans dan metabolit darah kambing Boerka laktasi. JITV 25(1):32-39. DOI: http://dx.doi.org/10.14334/jitv.v25i1.2196.

Kambing dalam masa laktasi rentan terhadap situasi neraca energi tubuh yang negatif akibat mobilisasi cadangan lemak tubuh untuk memenuhi kebutuhan energi yang meningkat untuk produksi susu.Penelitian bertujuan untuk mempelajari respons kambing fase laktasi terhadap dua sumber energi berbeda didalam pakan komplit. Penelitian dilakukan menggunakan 35 ekor kambing Boerka dengan paritas 2-3, bobot badan 30,3 $\pm 4,48 \mathrm{~kg}$ dan skor kondisi tubuh 2,5 $\pm 0,05$ skala 1-5 pada saat melahirkan. Ternak dialokasikan ke 5 perlakuan pakan (7 ekor/perlakuan) yang dirancang sedemikian rupa, sehingga isonitrogen dan iso-kalori. Tepung kasava digunakan sebagai sumber utama energi glukogenik dan bergafat digunakan sebagai sumber utama energy lipogenik. Pakan diberikan dalam bentuk pakan komplit pelet.Tidak terdapat perbedaan konsumsi pakan antara pakan glukogenik (rendah lemak 1,40 dan 2,28\%), namun berbeda nyata $(\mathrm{P}<0,05)$ dengan kelompok pakan lipogenik (kandungan lemak pakan 4,7-7,5\%). Selama laktasi kambing mengalami pertambahan berat badan pada kisaran 15-46 g/h yang mengindikasikan neraca energi positif pada semua perlakuan pakan. Kelompok dengan pakan energi lipogenik mengalami pertambahan berat badan, FCR dan skor kondisi tubuh yang lebih baik $(\mathrm{P}<0,05)$ dibandingkan dengan pakan dengan energi yang lebih glukogenik. Konsentrasi glukosa dan urea darah tidak dipengaruhi oleh perlakuan pakan $(\mathrm{P}>0,05)$, dan berturut-turut berkisar antara $37-43 \mathrm{mg} / \mathrm{dl}$ dan 39 to $51 \mathrm{mg} / \mathrm{dl}$. Namun, secara numerik konsentrasi glukosa dan urea darah meningkat secara linier pada kelompok yang mendapat pakan lipogenik yang konsisten dengan taraf konsumsi pakan. Disimpulkan bahwa pemberian pakan dengan sumber energi lipogenik (kandungan lemak 7,5\%) dalam bentuk pakan komplit pellet selama masa laktasi pada kambing menghasilkan taraf konsumsi pakan dan konsumsi nutrien dan PBB serta skor kondisi tubuh yang lebih tinggi dibandingkan dengan pemberian pakan dengan sumber energi glukogenik.
\end{abstract}

Kata Kunci: Pakan Glukogenik, Performa Kambing, Laktasi, Pakan Lipogenik

\section{ABSTRACT}

Ginting SP, Tarigan A, Simanihuruk S, Antonius, Solehuddin. 2020. Effects of two different energy sources in total mixed diets on the performances and blood metabolites of lactating Boerka goats. JITV 25(1):32-39. DOI: http://dx.doi.org/10.14334/jitv.v25i1.2196.

Lactating goats are prone to negative energy status due to increased body fat reserve mobilization to support the high energy requirement of milk production. The study was aimed to investigate the responses of the lactating goat on diets provided in total-mixed ration differing in the energy sources. The experiment was conducted using a total of 35 does having 2-3 parities and an average bodyweight of $30.3 \pm 4.48 \mathrm{~kg}$ and BCS of $2.5 \pm 0.05$ on a scale basis of 1 to 5 . Animals were allocated to one of five dietary treatments (seven animals/treatment) formulated to be iso-nitrogen dan iso-calory in a total mixed ration. Cassava meal was used as the source of glucogenic energy and bergafat as the main source of lipogenic energy. There were no DM intake differences $(\mathrm{P}>0.05)$ between the glucogenic diet $(1.49 \%$ and $2.28 \%$ fat $)$, but significant increases $(\mathrm{P}<0.05)$ in DM intake were observed in goats fed lipogenic diets (fat content range from 4.7 to $7.5 \%)$. All animals gained during the lactation period with ADG ranged from 15 to $46 \mathrm{~g}$, indicating that all experimental animals were in positive energy balances. Goat receiving more glucogenic diets gained least and having higher FCR compared to those receiving lipogenic diet $(\mathrm{P}<0.05)$. Body condition scores were also improved in lactating goat received more lipogenic diets. Blood glucose and blood urea concentration was not affected by diet treatments and lactation period ( $\mathrm{P}>0.05)$ and ranged from 37 to $43 \mathrm{mg} / \mathrm{dl}$ and 39 to $51 \mathrm{mg} / \mathrm{dl}$, respectively. Numerically, however, the blood glucose and urea level linearly increased as the diet becoming more lipogenic due to the increased feed intake. It is concluded that lactating goats offered diets with lipogenic energy sources ( $7.5 \%$ fat content) presented in pelleted total mixed-ration during the entire lactation period had a higher dry matter and nutrient intakes, body weight gain and body condition score compared to those fed diets with glucogenic energy source. 
Key Words: Glucogenic Diet, Goat Performance, Lactation, Lipogenic Diet

\section{INTRODUCTION}

Goat production in Indonesia is dominated by the smallholders based on the mixed-farming system or extensively grazing system. A more intensively and commercial goat production system where total-mixed ration (TMR) is practiced has been emerged, particularly in the densely populated area where land is becoming limited for agricultural activities while the demand for goat meat is increasing. TMR is considered to be suitable in providing nutrients in more precise amounts and balances as compared to conventional practices (Schingoethe 2017). This is particularly relevant during the lactation period when the nutrient and energy requirements are at the peak levels to support a high level of milk production (Goetsch 2019) and a reduction in feed intake may occur due to the metabolic and hormonal factors (van Knegsel et al. 2007). During the lactation state, the animals are therefore commonly experiencing a negative energy balance that will influence negatively their subsequent performances (van Knegsel et al. 2007). A feeding system that provides the animal's access to a high nutrient and energy density diet is thus required in order to prevent this phenomenon. Non-structural carbohydrate (NSC) or fat could be added to diet in order to increase the dietary energy density and total energy intake. However, the high concentration of both NSC and fat in the diet may provide negative effects on the ruminants. High NSC diet may increase the risk of a suboptimal rumen environment and could cause metabolic disorder such as acidosis (Wang et al. 2016; Shen et al. 2019), while high-fat diet may result in a decrease in fiber digestibility and forage intake (Weld \& Armentano 2017). Cassava meal was used as the main glycogenic energy source because it contained relatively high non fiber carbohydrate. In addition, cassava meal is widely available with competitive cost. Bergafat was used as the main lipogenic energy source since it is a rumen-protected fat so that minimum rumen fermentation disorder could be prevented when providing at relatively high level in diet. The present study was aimed to investigate the responses of lactating goats in terms of feed and nutrient and energy intakes, body weight changes, body condition scores and blood metabolites on diets differing in the energy sources provided in the total-mixed ration.

\section{MATERIALS AND METHODS}

\section{Animal and diets}

The experiment was conducted at the Indonesian Goat Research Station using a total of 35 does having 2-3 parities and average body weight of $30.3 \pm 4.48 \mathrm{~kg}$ and BCS of $2.5 \pm 0.05$ on a scale basis of 1 to 5 . All animals were in the state of late pregnancy and each animal was in an individual crate 2 to 3 weeks prior to the expected kidding time. During this time all animals were offered the same total-mixed ration to adapt them to this type of feed presentation prior to the next lactation period. Animals were then divided into five groups and randomly allocated to one of the five lactation diet treatments for the whole lactation period. Diets are designed to be iso-nitrogenous and isocaloric, but differing in the energy sources mainly by the differentiation of the inclusion rate of cassava meal as glucogenic energy source and fat as lipogenic energy source (Table 1). Bergafat (Berg+Scmidt) was used as a supplement to create lipogenic diet. This fat is a vegetable fat processed from palm oil and protected from rumen fermentation. Diet treatments were formulated such that the energy sources were mainly as glucogenic (TMR1), lipogenic (TMR5) or the combinations of glucogenic and lipogenic (TMR2, TMR3 and TMR4).

The forage to concentrate ratio of the experimental diets ranged from 25:75 to 35:65 (dry matter) using $I$. zollingeriana as the sole forage. The leaves of this leguminous tree were harvested every day in the morning and sun-dried immediately for 2 to 3 days before milled. All feed ingredients were mixed thoroughly using a horizontal mixer and were pelletized to yield total-mixed rations.

\section{Experimental procedures}

During the feeding trial lasting for 90 days, all does were fed ad libitum by allowing a refusal rate of 5 to 10 $\%$ twice daily in the morning (08:00) and in the afternoon (15:00). Each doe was confined in an individual cage of $1.5 \times 2.0$ m equipped with feed bunk designed to prevent the kid from access to the diets. Water was available all the time in a plastic container located outside the cage. Feed offered and refusals were recorded daily to calculate feed intake. Does and kids were weighed weekly and the does were scored for body conditions on the same date. Body condition scores were determined by a panel of three individuals as described by Ngwa et al. (2007). Samples of diets $(0.5 \mathrm{~kg})$ were taken weekly and put in the freezer ($20^{\circ} \mathrm{C}$ ) before analyses. The samples were composited and mixed thoroughly and subsampled for subsequent 
chemical analyses. Following the feeding trial, the animals were transferred into individual metabolism cage with a slatted wood floor for seven days as adaptation period and five days as the collection Table1. Ingredient compositions of the experimental total mixed rations (TMRs)

\begin{tabular}{|c|c|c|c|c|c|}
\hline \multirow{2}{*}{ Ingrediets, \% DM } & \multicolumn{5}{|c|}{ Diet } \\
\hline & TMR1 & TMR2 & TMR3 & TMR4 & TMR5 \\
\hline I.zollingeriana leaf meal & 25.0 & 25.0 & 30.0 & 30.0 & 35.0 \\
\hline Cassava meal & 37.0 & 33.0 & 27.0 & 22.0 & 5.0 \\
\hline Soybean meal & 20.0 & 20.0 & 17.0 & 16.0 & 10.0 \\
\hline Palm kernel meal & 2.0 & 1.0 & 6.0 & 12.0 & 16.0 \\
\hline Bergafat & 1.0 & 1.0 & 2.5 & 5.0 & 5.0 \\
\hline Rice bran & 10.0 & 15.0 & 12.5 & 10.0 & 24.0 \\
\hline Bone meal & 1.0 & 1.0 & 1.0 & 1.0 & 1.0 \\
\hline Limestone & 1.0 & 1.0 & 1.0 & 1.0 & 1.0 \\
\hline Salt & 1.0 & 1.0 & 1.0 & 1.0 & 1.0 \\
\hline Molasses & 1.0 & 1.0 & 1.0 & 1.0 & 1.0 \\
\hline Mineral premix ${ }^{a}$ & 1.0 & 1.0 & 1.0 & 1.0 & 1.0 \\
\hline
\end{tabular}

sampled daily in polythene bags and total feces were weighed and samples $(10 \% \mathrm{w} / \mathrm{w})$ were taken and put in polythene bags. Feed and fecal samples were frozen at $20^{\circ} \mathrm{C}$ for each animal for further chemical analysis.

The dry matter content of diets and feces was determined by drying the samples in the oven at $60^{\circ} \mathrm{C}$ for $48 \mathrm{~h}$ and were ground to pass a $1-\mathrm{mm}$ screen in a Willey mill. Crude protein and fat contents were determined by the procedures of AOAC (2007). Neutral Detergent Fiber was analyzed according to the procedures of Van Soest et al. (1991). The gross energy of the diets was determined by the adiabatic calorimeter. Blood was collected from all does at 4, 8 and 12 weeks postpartum at 3 hours after morning feeding. Blood $(5.0 \mathrm{ml})$ was withdrawn from the jugular vein into vacutainer tubes containing lithium heparin. The tubes containing blood were centrifuged at $3,000 \mathrm{x} \mathrm{g}$ for $15 \mathrm{~min}$, and plasma was separated and kept in freezer at $-20^{\circ} \mathrm{C}$ for subsequent analyses. The colorimetric assay was performed to measure the plasma glucose.

\section{Statistical analysis}

The experiment was conducted in a completely randomized design with five treatments and seven replicates. Data were analyzed using analysis of period. The animals were fed at a level allowing minimal feed residues. During the collection period diets were variance using the procedure of the General Linear Model of Statistical Analysis System (SAS 2012). Duncan's multiple range tests was used to compare differences among treatment means using 0.05 level of significance (Steel \& Torrie 1980). 


\section{RESULTS AND DISCUSSION}

The experimental diets were considered to be isonitrogenous with $\mathrm{CP}$ contents ranging from 18.2 to $18.8 \%$ and iso-caloric with the ME contents ranging from 2940 to $2976 \mathrm{Kcal} / \mathrm{Kg}$ DM (Table 2). The TMR1 is considered as a glucogenic diet as it contained the highest level of non-fiber carbohydrate and the lowest level of ether extract, while the TMR5 is considered as a lipogenic diet as its ether extract and non-fiber concentration are the highest and the lowest, respectively. The level of NDF in the diets ranged from 31 to $37 \%$, which were in the safe level to prevent metabolic problems when feed is presented as a total mixed ration.

The level of DM intake ranged from $3.01-3.33 \%$ $\mathrm{BW}$ in all diet treatments which is considered to be normal for lactating goats. This also indicates that providing diet in the form of pelleted totally mixed ration could be practiced in an intensive goat production system. There were no DM intake differences $(\mathrm{P}>0.05)$ as the fat content increased from $1.49 \%$ (TMR1) to $2.28 \%$ (TMR2), but significant increases $(\mathrm{P}<0.05)$ in $\mathrm{DM}$ intake were observed in goats fed higher fat and lower NFE diets (TMR3, TMR4 and TMR5). Goats have been suggested to be less susceptible to negative effects of high dietary fat level on dry matter intake (Goetsch 2019). In the present study, diets were isocaloric and were provided as total mixed rations in pellet form which could have negated the possible negative effect of fat on palatability. Using bergafat as lipogenic supplement which is typically protected from

Table 2. Chemical compositions of the experimental total mixed rations (TMRs)

\begin{tabular}{|c|c|c|c|c|c|}
\hline \multirow[t]{2}{*}{ Nutrien } & \multicolumn{5}{|c|}{ Diet } \\
\hline & TMR1 & TMR2 & TMR3 & TMR4 & TMR5 \\
\hline Dry matter $(\mathrm{DM}), \%$ & 89.76 & 90.08 & 89.93 & 90.12 & 89.84 \\
\hline Organic matter, \% DM & 90.14 & 90.12 & 90.36 & 90.18 & 90.49 \\
\hline Crude protein, \% DM & 18.64 & 18.87 & 18.19 & 18.78 & 18.69 \\
\hline Ether extract, \% DM & 1.49 & 2.28 & 4.74 & 6.08 & 7.46 \\
\hline Crude fibre, $\%$ DM & 8.04 & 8.66 & 9.73 & 10.40 & 12.8 \\
\hline $\mathrm{NDF}, \% \mathrm{DM}$ & 31.09 & 32.65 & 34.62 & 36.14 & 37.83 \\
\hline Non fibre carbohydrate ${ }^{\mathrm{a}}, \% \mathrm{DM}$ & 38.92 & 36.32 & 32.80 & 29.18 & 26.51 \\
\hline Gross energy, Kcal/kg DM & 4742 & 4801 & 4709 & 4758 & 4767 \\
\hline Metabolizable energy ${ }^{\mathrm{b}}, \mathrm{Kcal} / \mathrm{kg}$ DM & 2940 & 2976 & 2920 & 2950 & 2956 \\
\hline
\end{tabular}

Results analysis of laboratory (AOAC 2007)

a Calculated according to Van Soest et al. (1991); bestimated using NRC (1981)

Table 3. Nutrient intake $(\mathrm{g} / \mathrm{head} / \mathrm{d})$ and metabolizable energy intake (ME, Kcal/head/d) and nutrient digestibility (\%) in lactating goat fed diets of different energy sources

\begin{tabular}{|c|c|c|c|c|c|}
\hline \multirow[t]{2}{*}{ Parameters } & \multicolumn{5}{|c|}{ Diet } \\
\hline & TMR1 & TMR2 & TMR3 & TMR4 & TMR5 \\
\hline \multicolumn{6}{|l|}{ Intake } \\
\hline Dry matter & $889 \pm 29.4^{\mathrm{a}}$ & $926 \pm 31.6^{\mathrm{a}}$ & $987 \pm 36.9^{b}$ & $981 \pm 27.5^{\mathrm{b}}$ & $1029 \pm 32,5^{b}$ \\
\hline Organic matter & $827 \pm 25.3^{\mathrm{a}}$ & $844 \pm 27.6^{\mathrm{a}}$ & $905 \pm 31.8^{\mathrm{b}}$ & $902 \pm 26.7^{b}$ & $940 \pm 28.4^{\mathrm{b}}$ \\
\hline Crude protein & $166 \pm 7.1^{\mathrm{a}}$ & $175 \pm 8.2^{\mathrm{a}}$ & $180 \pm 9.1^{\mathrm{a}}$ & $184 \pm 9.7^{b}$ & $192 \pm 9.4^{\mathrm{b}}$ \\
\hline Ether extract & $13.4 \pm 0.7^{\mathrm{a}}$ & $21.2 \pm 1.1^{\mathrm{b}}$ & $46.9 \pm 2.3^{c}$ & $67.3 \pm 2.8^{\mathrm{d}}$ & $76.1 \pm 2.7^{\mathrm{d}}$ \\
\hline ME, Kcal/day & $2614 \pm 116^{\mathrm{a}}$ & $2756 \pm 135^{b}$ & $2882 \pm 115^{c}$ & $2893 \pm 147^{\mathrm{d}}$ & $3041 \pm 146^{\mathrm{d}}$ \\
\hline NFC & $346 \pm 17.9^{\mathrm{a}}$ & $336 \pm 15.1^{\mathrm{a}}$ & $323 \pm 16.8^{\mathrm{a}}$ & $286 \pm 20.1^{\mathrm{b}}$ & $273 \pm 14.2^{\mathrm{b}}$ \\
\hline
\end{tabular}


JITV Vol. 25 No. 1 Th. 2020:32-39

\begin{tabular}{lccccc}
\hline NDF & $277 \pm 13.3^{\mathrm{a}}$ & $303 \pm 14.8^{\mathrm{a}}$ & $341 \pm 14.5^{\mathrm{b}}$ & $354 \pm 13.3^{\mathrm{b}}$ & $388 \pm 12.5^{\mathrm{c}}$ \\
Digestibility & & & & \\
Dry matter & $63.9 \pm 1.6^{\mathrm{a}}$ & $65.2 \pm 2.7^{\mathrm{a}}$ & $69.1 \pm 2.6^{\mathrm{b}}$ & $68.2 \pm 2.5^{\mathrm{b}}$ & $71.5 \pm 2,4^{\mathrm{b}}$ \\
Organic matter & $65.4 \pm 1.7^{\mathrm{a}}$ & $66.9 \pm 1.2^{\mathrm{a}}$ & $70.8 \pm 2.1^{\mathrm{b}}$ & $70.3 \pm 2.3^{\mathrm{b}}$ & $73.6 \pm 1.4^{\mathrm{b}}$ \\
Crude protein & $67.4 \pm 1.4^{\mathrm{a}}$ & $68.7 \pm 1.9^{\mathrm{a}}$ & $72.2 \pm 1.5 \mathrm{~b}^{\mathrm{ab}}$ & $72.5 \pm 1.4^{\mathrm{ab}}$ & $76.2 \pm 1.5 \mathrm{~b}^{\mathrm{b}}$ \\
Ether extract & $73.8 \pm 2.1^{\mathrm{a}}$ & $73.5 \pm 1.1^{\mathrm{a}}$ & $78.3 \pm 2,3^{\mathrm{a}}$ & $85.2 \pm 2.3^{\mathrm{b}}$ & $87.8 \pm 2.0^{\mathrm{b}}$ \\
NFC & $91.5 \pm 3.8$ & $92.2 \pm 4.3$ & $89.7 \pm 3.1$ & $90.4 \pm 2.6$ & $91.1 \pm 3.7$ \\
NDF & $58.4 \pm 2,3^{\mathrm{a}}$ & $59.2 \pm 1.6^{\mathrm{a}}$ & $54.8 \pm 1.7^{\mathrm{b}}$ & $52.4 \pm 2.5^{\mathrm{ab}}$ & $51.3 \pm 1.3^{\mathrm{b}}$ \\
\hline
\end{tabular}

$\overline{a, b, c, d}$ Different superscripts in the same row significantly differ $(\mathrm{P}<0,05)$ 
the rumen fermentation could have been also an important factor. The lower feed intake in glucogenic diet (TMR1 and TMR2) could also be related to the high NFC content. Although the experimental diets contained $25 \%$ roughage the decrease of rumen $\mathrm{pH}$ in the glucogenic diets was expected since the glucogenic contain a high level of cassava meal (33-37\%), which is rapidly degraded in the rumen. This low $\mathrm{pH}$ may result in less feed intake. Although the rumen $\mathrm{pH}$ was not measured in the present experiment, Shen et al. (2019) observed that the rumen $\mathrm{pH}$ decreased to 5.36 when the high starch diet was fed to a goat. In the present study, the starch is represented by NFC and ranged from 36-39\%. Mudgal et al. (2012) however did not find a significant effect of supplementing bypass fat on feed intake in lactating crossbred cows.

There was a consistent increase in intake and digestibility of DM, OM, CP and EE as the fat content of diet increased, but NDF digestibility decreased as the fat content of diet increase. This is consistent with Atikah et al. (2018) that CP and EE digestibility in goat increased with the increasing level of fat in the diet. Bhatt et al. (2013a) however indicated that the digestibility of NDF, EE and CP was improved when $\mathrm{Ca}$ protected fat was supplemented in ewes. The increased CP intake is associated with greater DM intake. The greater $\mathrm{CP}$ intake and digestibility resulted in greater intake of digestible protein as the fat content of the diet increased. The digestible protein intake ranged from 111 to $146 \mathrm{~g} / \mathrm{d}$ in all treatments which is predicted to be sufficient for lactating goats.

Bodyweight changes of the lactating goats are presented in Table 4. All animals gained during the lactation period with ADG ranged from 15 to $46 \mathrm{~g}$ indicating positive energy balances. Goat receiving more glucogenic diets (TMR1 and TMR2) gained the least and those receiving the most lipogenic diet (TMR5) gained most $(\mathrm{P}<0.05)$. The ADG linearly increased as the percentage of fat in diets increased up to $7.5 \%$ i.e. as the diet becoming more lipogenic. This is consistent with Vakili et al. (2011) indicating that diet with the fat content of $6.7 \%$ had potential to improve the energy balance state of sheep compared to a glucogenic diet. Consistent findings were also reported by Bhatt et al. (2013b) in lambs and Bhatt \& Sahoo (2017) in ewes that growth was improved in diet with higher fat content. In tropical dairy cows (Mobeen et al. 2017) and in non-lactation ewes, however, Behan et al. (2019) did not found a significant effect of increasing the fat content of diet from 4.9 to $8.4 \%$ by supplementing protected fat. In the present study, body condition scores were also improved in lactating goat received more lipogenic diets. These increased in body weight and body condition scores might have related to greater DM and nutrient intakes and efficiency of energy utilization (Park et al. 2010; Bhatt \& Sahoo 2017). The ration of high producing animal like a lactating goat should contain 4 to $6 \%$ fat of natural and protected fat (Naik 2013), while in dairy cow, Palmquist \& Jenkins (2017) suggested that more than 3\% fat in diet is required to maintain appropriate body condition. The efficiency of feed utilization as indicated by the FCR value (g DM intake/g ADG) showed that lactating goats utilized feed more efficiently for body weight gain as the energy source of the diet was more lipogenic $(\mathrm{P}<0.05)$. In the present study, the FCR for body weight gain ranged from 22.15 (lipogenic diet) to 58.79 (glucogenic diet). This low efficiency of feed utilization for body weight gain was indicative of more diet that has been directed for milk production.

Blood glucose concentration (Table 5) was not affected by diet treatments nor by lactation period $(\mathrm{P}>0.05)$. The blood glucose levels in all diet treatments ranged from 53 to $58 \mathrm{mg} / \mathrm{dl}$. Numerically, the blood glucose level tends to increase as the diet becomes more lipopgenic. The blood glucose concentrations were consistent with feed intake for all treatments. These levels are consistent with Singh \& Ludri (2002) reporting the blood glucose level in 30, 60 and 90 lactation periods between $49-57 \mathrm{mg} / \mathrm{dl}$. Range of glucose levels of 60 to $71 \mathrm{mg} / \mathrm{dl}$ in several breeds of the goat during lacatatin maintained under intensive production system was reported by Mohammed et al. (2016). It was expected the blood glucose level in goats offered glukogenic diet was higher than the lipogenic group since more propionic acid would have been produced from NFC fermentation in the rumen which is an important glucose precursor through the gluconeogenesis pathway. The nonsignificant effect $(\mathrm{P}>0.05)$ observed in the present study could be due to similar gluconeogenesis rate using amino acids as precursor of glucose in the lipogenic group. During the lactation period the blood insulin level is commonly decreasing in ruminant (Karapehlivan et al. 2007), and this may relate to the relatively high blood glucose level in the lactating goat as observed in the current experiment. The lower level of blood glucose in non-lactating goats of $46-48$ $\mathrm{mg} / \mathrm{dl}$ has been reported (Bansode et al. 2019).

The blood urea concentration (Table 5) was not affected by diet treatment nor by the lactation period $(\mathrm{P}>0.05)$. The blood urea concentration in all diet treatments ranged from $37-43 \mathrm{mg} / \mathrm{dl}$. Numerically, the blood urea levels were higher in the mid and late lactation as compared to early lactation. The lower blood urea concentration in the early lactation is expected since it is related to the level of protein intake 
and feed intake which is usually lower during the the range of blood urea concentration between 25 and period. Kohn et al. (2005) in his review indicated that

Table 4. Body weight changes and body condition scores of lactating goat offered diets of different energy sources

\begin{tabular}{llllll}
\hline \hline \multirow{2}{*}{ Parameter } & \multicolumn{5}{c}{ Diet } \\
\cline { 2 - 6 } & TMR1 & TMR2 & TMR3 & TMR4 & TMR5 \\
\hline Initial BW,kg & $29.13 \pm 1.33$ & $29.15 \pm 1.25$ & $28.28 \pm 1.26$ & $27.36 \pm 1.47$ & $28.76 \pm 1.59$ \\
Final BW,kg & $30.50 \pm 1.91$ & $30.40 \pm 1.59$ & $30.92 \pm 1.06$ & $30.32 \pm 1.15$ & $32.94 \pm 1.66$ \\
BW change,kg & $1.4 \pm 0.07^{\mathrm{a}}$ & $1.3 \pm 0.08^{\mathrm{a}}$ & $2.6 \pm 0.11^{\mathrm{b}}$ & $3.01 \pm 0.15^{\mathrm{c}}$ & $4.17 \pm 0.11^{\mathrm{d}}$ \\
ADG,g & $15.12 \pm 0.98^{\mathrm{a}}$ & $14.55 \pm 1.43^{\mathrm{a}}$ & $28.32 \pm 2.97^{\mathrm{b}}$ & $33.89 \pm 1.24^{\mathrm{c}}$ & $46.45 \pm 2.11^{\mathrm{d}}$ \\
FCR & $58.79 \pm 3.53^{\mathrm{a}}$ & $63.6 \pm 4.45^{\mathrm{a}}$ & $34.87 \pm 1.67^{\mathrm{b}}$ & $28.9 \pm 1.88^{\mathrm{c}}$ & $22.15 \pm 1.55^{\mathrm{d}}$ \\
BCS & $2.56 \pm 0.25^{\mathrm{a}}$ & $2.53 \pm 0.19^{\mathrm{a}}$ & $2.69 \pm 0.23^{\mathrm{b}}$ & $2.76 \pm 0.21^{\mathrm{b}}$ & $2.73 \pm 0.19^{\mathrm{b}}$ \\
\hline
\end{tabular}

a,b,c,d Different superscripts in the same row significantly differ ( $<<0,05)$; FCR:DM intake/ADG (g/g)

Table 5. Blood glucose and urea- $\mathrm{N}$ concentration in lactating Boerka goat offered total mixed ration differing in energy sources

\begin{tabular}{|c|c|c|c|c|c|}
\hline \multirow{2}{*}{$\begin{array}{l}\text { Lactation, } \\
\text { days }\end{array}$} & \multicolumn{5}{|c|}{ Diet } \\
\hline & TMR & TMR2 & TMR3 & TMR4 & TMR5 \\
\hline & \multicolumn{5}{|c|}{ Blood glucose, $\mathrm{mg} / \mathrm{dl}$} \\
\hline 30 & $53,01 \pm 4,82$ & $54,65 \pm 3,97$ & $58,85 \pm 4,85$ & $57,80 \pm 2,66$ & $58,18 \pm 11,9$ \\
\hline 60 & $54,17 \pm 4,03$ & $52,67 \pm 3,89$ & $53,65 \pm 4,45$ & $56,74 \pm 5,13$ & $55,50 \pm 3,18$ \\
\hline \multirow[t]{2}{*}{90} & $54,51 \pm 4,85$ & $54,14 \pm 3,81$ & $58,37 \pm 3,96$ & $58,44 \pm 2,95$ & $57,49 \pm 4,92$ \\
\hline & \multicolumn{5}{|c|}{ Blood urea-N,mg/dl } \\
\hline 30 & $38,58 \pm 2,49$ & $34,48 \pm 2,11$ & $37,65 \pm 2,23$ & $35,60 \pm 2,93$ & $37,50 \pm 2,51$ \\
\hline 60 & $41,14 \pm 2,74$ & $39,0 \pm 3,20$ & $41,64 \pm 1,27$ & $42,20 \pm 3,31$ & $39,19 \pm 3,17$ \\
\hline 90 & $41,35 \pm 1,19$ & $41,40 \pm 1,59$ & $42,28 \pm 2,86$ & $43,22 \pm 2,16$ & $42,75 \pm 3,51$ \\
\hline
\end{tabular}

$38 \mathrm{mg} / \mathrm{dl}$. Maintained under intensive production system Mohammed et al. (2016) observed urea blood levels of 27 to $37 \mathrm{mg} / \mathrm{dl}$ in different breeds of goat. The relatively high blood urea level observed in the present experiment may be related to the relatively high intake of crude protein (166 - 192 g/d) from diet with 18\% crude protein level. In addition, the major protein source of all diet treatment was leguminous leaves of I.zollingeriana of high rumen degradability (Tarigan et al., 2010) and soybean meal which is highly soluble in the rumen. The non-significant effect $(\mathrm{P}>0.05)$ of diets differing in crude protein intake with similar protein degradation rate on the level of urea blood concentrations indicated that there was sufficient energy for microbial utilization of nitrogen in the rumen for optimum microbial protein synthesis in all diet treatments. The relatively high blood urea levels observed in the present experiment, however, are comparable to $40-56 \mathrm{mg} / \mathrm{dl}$ observed by Adiwinarti et al. (2018) in Kacang goat fed complete feed. Kumagai \& Ngampongsai (2006) indicated a linear 
relationship between an increased blood urea levels with the crude protein level of diet in goats. Thus, it is indicated from this experiment that lipogenic or glucogenic diets did not affect the concentration of urea blood level.

\section{CONCLUSION}

Presentation of feed as pelleted total mixed-ration provides normal feed and nutrient intakes in goat during the whole lactation period. Compared to lactating goats fed diet with higher glucogenic energy, those offered diet with more lipogenic energy by increasing the fat content of the diet up to $7.5 \%$ responded better in term of feed intake, nutrient intakes, ADG and BCS. As the protected fat is used to increase the energy content of the lipogenic diets, it is uncertain, however, wether these responses have been consistent when the energy lipogenicity of the diet has been increased by increasing the fat content level greater than $7.5 \%$ or when non protected fat has been used. 


\section{REFERENCES}

Adiwinarti R, Kustantinah, Budisatria IGS, Rusman, Indarto E. 2018. Profile of Rumen Fermentation and Blood Urea Nitrogen Concentration of Kacang Goat Fed Total Mixed Ration Vs. Roughage. IOP Conf Ser Earth Environ Sci. 119:1-5.

AOAC. 2007. Official Methods of Analyses. Washington DC (USA): Association of Official Analythical Chemists.

Atikah IN, Alimon AR, Yaakub H, Abdullah N, Jahromi MF, Ivan M, Samsudin AA. 2018. Profiling of rumen fermentation, microbial population and digestibility in goats fed with dietary oils containing different fatty acids. BMC Vet Res. 14:344-353.

Bansode S, Swami J, Shahapure S. 2019. Effects of differing system on the physiological and hematological parameters of Osmanabadi kids. Int J Sci Environ Technol. 8:35-43.

Behan AA, Loh TC, Fakurazi S, Kaka U, Kaka A, Samsudin AA. 2019. Effects of Supplementation of Rumen Protected Fats on Rumen Ecology and Digestibility of Nutrients in Sheep. Animals. 9:400-418.

Bhatt R, Karim S, Sahoo A, Shinde A. 2013. Growth Performance of Lambs Fed Diet Supplemented with Rice Bran Oil as Such or as Calcium Soap. AsianAustralasian J Anim Sci. 26:812-819.

Bhatt RS, Sahoo A. 2017. Effect of feeding complete feed block containing rumen protected protein, non-protein nitrogen and rumen protected fat on improving body condition and carcass traits of cull ewes. J Anim Physiol Anim Nutr (Berl). 101:1147-1158.

Bhatt RS, Sahoo A, Shinde AK, Karim SA. 2013. Change in body condition and carcass characteristics of cull ewes fed diets supplemented with rumen bypass fat. Livest Sci. 157:132-140

Goetsch AL. 2019. Recent advances in the feeding and nutrition of dairy goats. Asian-Australasian J Anim Sci. 32:1296-1305.

Karapehlivan M, Atakisi E, Atakisi O, Yucayurt R, Pancarci SM. 2007. Blood biochemical parameters during the lactation and dry period in Tuj ewes. Small Rumin Res. 73:267-271.

van Knegsel ATM, van den Brand H, Graat EAM, Dijkstra J, Jorritsma R, Decuypere E, Tamminga S, Kemp B. 2007. Dietary Energy Source in Dairy Cows in Early Lactation: Metabolites and Metabolic Hormones. J Dairy Sci. 90:1477-1485.

Kohn RA, Dinneen MM, Russek-Cohen E. 2005. Using blood urea nitrogen to predict nitrogen excretion and efficiency of nitrogen utilization in cattle, sheep, goats, horses, pigs, and rats1. J Anim Sci. 83:879-889. A

Kumagai H, Ngampongsai W. 2006. Comparative studies on dry matter intake, digestibility and nitrogen metabolism between Thai native (TN) and Anglo Nubian×TN bucks. Small Rumin Res. 66:129-134.

Mobeen A, Riaz M, Yaqoob M. 2017. Effects of by-pass fat supplementation q on the performance of Sahiwal dairy cows. Biol Int J Agric. 19:423-426.

Mohammed SA, Mohammed AR, Omar AE, Albert S, AlGallaf WM. 2016. Biochemical and hematological profile of different breeds of goat maintained under intensive production system. African J Biotechnol. 15:1253-1257.

Mudgal V, Baghel R, Ganie A, Srivastava S. 2012. Effect of feeding bypass fat on intake and production performance of lactating crossbred cow. Indian J Anim Res. 46:103-104.

Naik PK. 2013. By-pass fat in dairy ration: A Review. Anim Nutr Feed Technol. 13:147-163.

[NRC] National Research Council. 1981. Nutrient Requirements of Domestic Animals. Number 15. Nutrient Requirement of Goats: Angora, Dairy, and Meat Goats in Temperate and Tropical Countries. Washington DC (USA): National Academy of Science.

Ngwa AT, Dawson LJ, Puchala R, Detweiler G, Merkel RC, Tovar-Luna I, Sahlu T, Ferrell CL, Goetsch AL. 2007. Urea space and body condition score to predict body composition of meat goats. Small Rumin Res. 73:2736.

Palmquist DL, Jenkins TC. 2017. A 100-Year Review: Fat feeding of dairy cows. J Dairy Sci. 100:10061-10077.

Park BK, Choi N-J, Kim HC, Kim T Il, Cho YM, Oh YK, Im SK, Kim YJ, Chang JS, Hwang IH, et al. 2010. Effects of Amino Acid-enriched Ruminally Protected Fatty Acids on Plasma Metabolites, Growth Performance and Carcass Characteristics of Hanwoo Steers. AsianAustralasian J Anim Sci. 23:1013-1021.

SAS. 2012. SAS User's Guide: Statistic. New York (USA): SAS Institute Inc

Schingoethe DJ. 2017. A 100-Year Review: Total mixed ration feeding of dairy cows. J Dairy Sci. 100:1014310150.

Shen Y, Zhao F, Yu L, Yang W, Wang M, Wang H. 2019. Starch sources and concentration in diet of dairy goats affected ruminal $\mathrm{pH}$ and fermentation, and inflammatory response. Anim Prod Sci. 59:1640.

Singh M, Ludri RS. 2002. Milk Production, Blood Metabolites and Circulatory Levels of Hormones in Crossbred Goats. Asian-Australasian J Anim Sci. 15:963-967.

Van Soest PJ, Robertson JB, Lewis BA. 1991. Methods for Dietary Fiber, Neutral Detergent Fiber, and Nonstarch Polysaccharides in Relation to Animal Nutrition. J Dairy Sci. 74:3583-3597. 
Steel R, Torrie J. 1980. Principles and Procedures os Statistics: A Biometrical Approach. 2nd ed. New York (USA): McGraw-Hill Book Company.

Tarigan A, Abdullah L, Ginting S, Permana I. 2010. Produksi dan komposisi nutrisi serta kecernaan In vitro Indigofera sp pada interval dan tinggi pemotongan berbeda. JITV. 15:188-195.

Vakili A, Mortezaee A, Mesgaran MD. 2011. The effect of glucogenic and lipogenic diets on blood metabolites of
Baloochi sheep. Int J Anim Vet Sci. 11:794-796.

Wang SP, Wang WJ, Tan ZL. 2016. Effects of dietary starch types on rumen fermentation and blood profile in goats. Czech J Anim Sci. 61:32-41.

Weld KA, Armentano LE. 2017. The effects of adding fat to diets of lactating dairy cows on total-tract neutral detergent fiber digestibility: A meta-analysis. J Dairy Sci. 100:1766-1779. 